\title{
THE MODEL OF CLINICAL REASONING IN APPROACH TO FEBRILE INFECTIOUS DISEASES IN MEDIEVAL PERSIA
}

\section{MODEL KLINIČKOG ZAKLJUČIVANJA U PRISTUPU FEBRILNIM ZARAZNIM BOLESTIMA U SREDNJOVJEKOVNOJ PERZIJI}

\author{
Mojdeh Firouzi", Majid Dadmehr**, \\ Seyed Kamran Soltani Arabshah ${ }^{* * *}$, Mohsen Bahrami ${ }^{* * * *}$
}

\begin{abstract}
SUMMARY
Reviewing ancient manuscripts of Persian medicine (PM) reveals that there have been some basic principles for decision-making in epidemic infectious diseases that existed in the past. These PM rules for clinical reasoning were applied through a personalized approach along with public health advice in such situations. Currently, the coronavirus pandemic has been the biggest problem in the world. Its mainstay of treatment is based on preventative measures
\end{abstract}

* Research Institute for Islamic and Complementary Medicine, Iran University of Medical Sciences, Tehran, Iran; School of Persian Medicine, Iran University of Medical Sciences, Tehran, Iran. ORCID: https://orcid.org/0000-0002-9271-0936.

** Research Institute for Islamic and Complementary Medicine, Iran University of Medical Sciences, Tehran, Iran; School of Persian Medicine, Iran University of Medical Sciences, Tehran, Iran. ORCID: https://orcid.org/0000-0002-7032-8648.

*** Medical Education Department, Faculty of Medicine, CERMS (Center of Educational Research in Medical Sciences), Iran University of Medical Sciences, Tehran, Iran. ORCID: https://orcid.org/0000-0002-9016-2593.

**** Research Institute for Islamic and Complementary Medicine, Iran University of Medical Sciences, Tehran, Iran; School of Persian Medicine, Iran University of Medical Sciences, Tehran, Iran. ORCID: https://orcid.org/0000-0001-6567-3749.

Correspondence Address: Mohsen Bahrami, Faculty of Persian Medicine, Iran University of Medical Sciences, Behesht St. Vahdat Islami St. Tehran, Tehran, 1114733311, Iran. E-mail: bahramiazam26@ gmail.com. 
and symptomatic treatments. Meanwhile, traditional medical systems for providing preventive, supportive, and rehabilitative care to patients have received more attention than before. Thus, the specific individual approach considered by PM scholars for clinical courses of epidemic infectious diseases may help shed more light on the spread of knowledge on epidemic diseases in ancient Persia.

Keywords: clinical reasoning, history of medicine, Persian medicine, Avicenna, infectious disease, epidemic

\section{INTRODUCTION}

Clinical reasoning is the thinking process in the physician's mind for decision-making and managing the patient's medical problems. Eventually, the cluster of data and thoughts are sorted logically to make appropriate decisions (Daly, 20I8; Pelaccia et al., 20II). For about fifty years, the way physicians reason in clinical approaches has been noticed under the topic of clinical reasoning, and this concept remains complex and ambiguous (Lawson-Frost, 2019; Yazdani \& Hoseini Abardeh, 2019).

Reviewing ancient medical manuscripts shows that clinical reasoning has a long history, and ancient Persian medicine (PM) scholars proposed the clinical reasoning principles in the approach to diseases. They described their observations and rational discussions in their books (Ghaffari et al., 2017). Over thousands of years ago, PM physicians described methods of dealing with the patients in their medical textbooks. They have mainly employed theories of Hippocratic and Galenic medicine and established principles for the diagnosis and treatment of patients. The Persian scholars explained the definition and mechanisms of each disease, accurately classified their causes, and then described the signs and symptoms of each disease. They considered individual factors and focused on the management of the patient rather than the disease through a personalized approach.

In medieval Persia, there were some famous distinguished physicians whose fundamental medical books were impressive sources in the history of medicine. They wrote original authentic sources of PM that had an influence on medical science in Europe likewise. They made various contributions to medicine, including neurology, cardiology, pediatrics, pharmacy, etc. (Bahrami, 2020; Diamantis, Sidiropoulou \& Magiorkinis, 20ıо; Nezhad \& Dalfardi, 20I4; Rahimi et al., 2007). Rhazi (865-925 AD), Ahvazi (949-982 AD), and Ibn-e Sina (980-I037 AD) were prominent medical scholars in medieval Persia and had a significant role in developing the medicine in Islamic Golden Age (9-I2th century AD) (Changizi et al., 20II; Heydari, Hashempur, \& Zargaran, 
2013; Ahmed, 2008). Razi (currently known as Rhazes) was born and grew up in the Ray, one of the oldest cities of Iran. He emphasized clinical visits in the hospitals and medical education. Razi created a bedside teaching system with consecutive ward rounds and gathered his clinical experiences in his fundamental medical science books (Aciduman \& Belen, 2009; Zarshenas et al., 2012). Ibn-e Sina was born in a city of old Persia called Bokhara. He is known as Avicenna or "Prince of Physicians" in the Western world (Zargaran et al., 2012). Ibn-e Sina had a logical aspect and an evidence-based approach in medical science that has been unique (Shoja et al., 20II).

The term "Istidlal" is used in the PM textbooks, which is the counterpart of clinical reasoning in the current nomenclature. Ahvazi, also known as Haly Abbas in the West, was born in Ahvaz in Iran. He published his experiences more practical and systematically (Aciduman et al., 20I4; Zargaran et al., 2013). Ahvazi focused on medical education in his book "Kamil al-Sinaat al-Tibbiyya" and carefully categorized the book's contents for educational purposes. He considered the basic principles of medical education and provided a great insight into the concept of clinical reasoning as well. Ahvazi assigned a specific chapter to the topic of "reasoning in approaching diseases" or "Istidlal ala al-Amrad", which described the clinical reasoning for medical students in detail, and was clearly more comprehensive than the past PM scholars' descriptions. He explained data collection by history taking and physical examinations and discussed the interpretation of data in general terms and then specific to each disease (Ahvazi, 2008; Firouzi et al., 2019).

The clinical reasoning in PM was based on thinking and experiences. Evidence-based medicine existed in the ancient Persian medical textbooks, and PM scientists' therapeutic experiences were recorded in detail (Ghaffari et al., 2017; Sajadi, Mansouri, \& Sajadi, 2009). Owing to the lack of paraclinical diagnostic facilities, ancient physicians were careful clinical observers who focused more on each patient's bedside. Thus, facility shortage in the past could become an advantage for the improvement of thinking and reasoning of physicians so that they could even approach unknown diseases. Since the PM physicians had followed a rational, personalized, and evidence-based approach to clinical decision-making, they could reason and make decisions in different conditions, including epidemics of novel diseases.

Currently, the coronavirus pandemic has been the biggest challenge all over the world, and the mainstay of treatment is based on preventative measures and management of patient symptoms. Meanwhile, traditional medical systems for providing possible preventive, supportive, and rehabilitative care 
to patients have received more attention than before (Nikhat \& Fazil, 2020). Thus, the specific individual approach considered by PM scholars for clinical courses of epidemic infectious diseases may help shed more light on the spread of knowledge on epidemic diseases in ancient Persia and may introduce inexpensive, affordable, and versatile treatment options for such a communicable disease.

In this study, we aim to provide an overview of the concept of clinical reasoning in the approach to epidemic infectious diseases in ancient Persia.

\section{Epidemics in medieval Persia}

Historical evidence reveals that there were epidemic diseases in the past societies that spread quickly and affected many people. The experiences of ancient physicians in such communicable diseases are available in their medical resources. The infectious diseases have been well explained in the Hippocratic and Galen's epidemics textbooks (Langholf, 20Ir; Pappas, Kiriaze \& Falagas, 2008). Also, Persian scholars such as Ahvazi, Razi, and Ibn-e Sina described epidemic diseases in their books. They explained how they made decisions regarding those infectious and epidemic diseases (Ahvazi, 2008; Avicenna, 2005; Rhazes, 1886). Based on PM, even in the context of epidemics, an individualized approach is emphasized during the clinical reasoning process, in which patient's symptoms and characteristics were evaluated individually for more accurate diagnosis and treatment. However, their explanations corresponded with those times, and it is impossible to resemble a disease exactly the same as the epidemics of novel diseases such as coronavirus disease 2019 (COVID-Ig).

Ibn-e Sina pointed out the modes of transmission of infection. He indicated that epidemics could spread "like a message" from one person to another, as well as from one city to another. Furthermore, there was a belief that there would always be a history of common things during epidemics, such as place, food, drink, or travel history (Nikhat \& Fazil, 2020).

In ancient Persian manuscripts, prevention was emphasized in the epidemic situation. Thus, public health advice was given to people, e.g., staying at home to isolate and self-quarantine, disinfecting the houses with some available substances such as vinegar, and eating the right foods (Avicenna, 2005; Rhazes, 1886). Today, we have identified microorganisms as the causal agents of infectious diseases, but they were not known in the past. However, it might be interesting to review the general principles that ancient physi- 
cians used to treat communicable diseases. Their method has been based on careful observations and rational approaches in which individual host factors were considered through accurate clinical reasoning.

\section{Clinical Reasoning in the context Of Infectious epidemics in Persian Medicine}

In the PM manuscripts, epidemic diseases or "Amrad-al-Wabaiyya" were communicable diseases caused by environmental agents and described in the chapter of febrile diseases under the topic of "Hommayat" in detail. Fever was considered an unusual heat in the body with certain classifications based on its different etiologies, and some febrile conditions occur as epidemics. Fever by itself is an illness or a common side effect of another illness.

According to the viewpoint of PM scholars, there are various types of fevers, such as infectious fevers or "Hommayat-al-Ofuniyya", classified into different types. One of them is epidemic fever "Homma-al-Wabaiyya". In the PM books, this fever is described as an infectious fever that can affect most communities. Different areas are affected alternatively as climatic issues and seasons play a significant role in causing epidemic fever. This description shows that this type of fever is communicable and can lead to disease outbreaks, such as epidemics and pandemics.

The epidemic fever consists of several contagious diseases with variable presentations, and the way they are transmitted is mostly the respiratory tract. The epidemic fever eventually manifests in the form of other types of infectious fever, so ancient scholars emphasized careful examination and follow-up of any patient with epidemic fever to determine the final diagnosis. In all types of infectious fevers, predisposing factors lead to increased susceptibility to infection, the progression of the disease, and increased complications (Ahvazi, 2008; Avicenna, 2005; Rhazes, 1886).

However, differences in individual susceptibility to the epidemic diseases were also expressed. Ibn-e Sina, in his masterpiece textbook "The Canon of Medicine", explained the predisposing factors of infection, as poor lifestyle choices such as incompatible food combination, improper food preparation, consumption of unhealthy foods, sleep disorders, psychological stress, and environmental contaminations. In the chapter on epidemic fever, "Homma-al-Wabaiyya", he says:

"...The susceptibility to infectious epidemic fever varies from person to person, and the presence of body weakness or accumulation of excess excretory mate- 
rial in the body, due to overeating or lack of proper excretion, plays a pivotal role in the probability of the infection..." (Avicenna, 2005)

Based on PM, infectious fevers can cause complications throughout the body and manifest as a syndrome; therefore, all of the body organs can be involved in it. In this regard, Ahvazi (2008) states:

"Infectious fever starts from infection of the body's humors and warms the body, organ by organ, and reaches the heart and spreads from the arteries to all organs of the body."

Moreover, based on the viewpoint of Ibn-e Sina, people with an underlying disease or a weak constitution are more prone to epidemic diseases and have a poor prognosis (Nikhat \& Fazil, 2020). Ibn-e Sina stated that fever at the beginning of an infectious disease might be undetectable. This condition is called "Malilah", which is a prodromal period for infectious fevers. The patient only feels mild symptoms in this condition, including subjective warmth feeling, malaise, fatigue, yawning, mild myalgia, and mild headache. On the other hand, fever may not be obvious and may even present with chills. In the epidemic of infectious febrile disease, some non-specific primary symptoms include weakness, fatigue, yellowish face skin, anorexia, nausea, diarrhea, thirst, headache, shortness of breath, and changes in pulse and breathing rhythm (Avicenna, 2005). Then, each patient is observed for more specific clinical symptoms, which may differ individually. The type of febrile disease will be determined, and the treatment plan will become more apparent. Individual characteristics are important to delineate the clinical presentation, severity, and prognosis of an acute febrile disease and finally help to choose appropriate treatment options (Ahvazi, 2008; Avicenna, 2005). Ibn-e Sina suggested that the current clinical features of the disease in a patient determine the condition of the disease as a main part of the clinical reasoning process.

“...Appetite, thirst, respiratory status, accompanying symptoms such as headache, insomnia, delirium, anxiety, etc. play a key role in determining the status of febrile illnesses by which the severity of the disease, the type of fever, and prognosis of the disease are reasoned." (Avicenna, 2005)

Therefore, the prognosis of the disease is determined after diagnosis based on the quality and intensity of fever, the duration of fever, facial skin color changes, body excretion, and symptom differentiation such as swelling of the eyelids, anxiety, delirium, insomnia, and appearance of other new symptoms or complications (Avicenna, 2005). 
Among these febrile contagious diseases, various respiratory infectious diseases are described in PM literature (Iranzadasl et al., 202I). Upper respiratory infections or "Zokam va Nazleh" and pneumonia or "Zat-al-Riyya", can be regarded as complications of epidemic respiratory infections, which have dominant symptoms of fever, cough, dyspnea, sore throat, etc. In the view of $\mathrm{PM}$, some other complications are expected in various organs through the courses of acute infectious diseases or "Hommayat-al-Ofunyya".

Ahvazi, in his book entitled "The complete book of medicine", has presented a specific approach to diseases, especially in the field of febrile infectious diseases with innovation about climatic conditions. (Figure I) (Ahvazi, 2008).

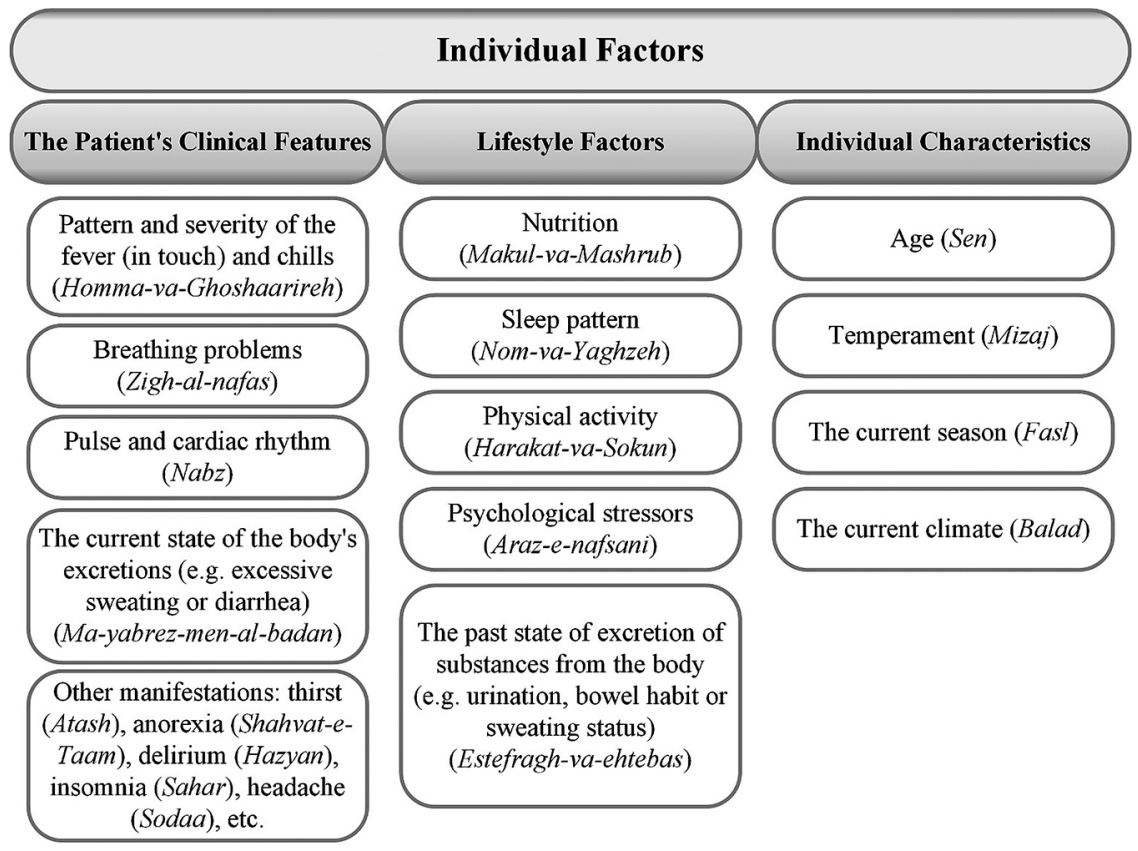

Figure I. Individual factors have to be considered in approach to febrile infectious diseases

Based on these factors, infected individuals can be categorized into one type of infectious fevers. Despite the variation in individual factors, they emphasized common recommendations. They also emphasized the need for individual observations even in approach to epidemics. In fact, they realized the range of symptoms and complications in infected people. Each person is classified in one of the categories of infectious diseases, and then in the next 
step, the patient's individual characteristics and his lifestyle are considered at the bedside, then the prognosis of his disease is discussed and finally, for each person the management is tailored to him to reduce complications (Ahvazi, 2008; Avicenna, 2005).

In the COVID-I9 epidemic, we face variable clinical manifestations and prognoses because of different host-pathogen interactions in spite of an obvious pathogen for the disease. In addition to the specific pathogenesis of the virus in the epidemic, the host-pathogen interactions depend on the host's individual characteristics, which are nowadays discussed again under the topics of genetics and epigenetics. Most of the factors raised by ancient Persian scholars in the field of lifestyle have been revived and reported as important underlying factors in the course of diseases (Binnie et al., 2020; Gurusamy \& Rajasingh, 2019; Maya et al., 2020; Schäfer \& Baric, 2017).

\section{Conclusion}

The current evidence shows that PM scholars were aware of the epidemic and had clinical reasoning in epidemic situations. Despite the lack of today's medical technology and knowing the culprit pathogen, they managed similar situations in the past via this approach. It was rational, experimental, and based on the patient's bedside. The PM scholars in their approach have considered personalized medicine and involved the patient as a central and active participant in the diagnosis and treatment of diseases. Based on their viewpoint, education and training the patients were some of the most important components of treatment options. Over the years, Persian physicians focused on individual characteristics and manifestations of each patient to suggest appropriate personalized treatment as a therapeutic approach to the epidemics.

Hundreds of years ago, there was an important treatment principle in the PM, which focused on the modification of lifestyles and choosing functional foods even in approach to epidemics. This effect may work by improving the interaction of the environment with the body that is the shelter of an infectious agent. Today, the role of epigenetic modification, such as nutrition, physical activity, psychological stress, sleep status, and environmental contacts in the clinical picture and severity of diseases such as infectious diseases, has been identified. Especially, a strong link between nutrition and various diseases in the prevention and treatment of diseases has also been proven based on current studies. 
We hypothesize that individuals' characteristics considered by PM scholars for clinical courses of infectious diseases might imply the immunological status of the patients as a prominent factor. Therefore, identifying and modification of these individuals' factors are important in the clinical reasoning based on PM and can be helpful to control a new communicable disease by introducing inexpensive, affordable, and versatile treatment options.

\section{Acknowledgments}

This manuscript is extracted from a part of $\mathrm{PhD}$ thesis (in progress) by the first author, Mojdeh Firouzi, at Iran University of Medical Sciences, Tehran, Iran.

\section{LITERATURE}

1. Aciduman, A., Arda, B., Aşkit, Ç., Belen, D. \& Tuzcu, K. (2014). Account of Haly Abbas regarding the management of hydrocephalus in children: a text from medieval times. World neurosurgery, 82(6), e791-e796. https://doi.org/10.1016/j. wneu.2013.07.077

2. Aciduman, A. \& Belen, D. (2009). Hydrocephalus and its treatment according to Rhazes. Journal of Neurosurgery: Pediatrics, 3, 161-165. https://doi.org/10.3171/2008.12. PEDS08201

3. Ahmed, S. A. (2008). Islam and Scientific Enterprise. IK International Pvt Ltd.

4. Ahvazi, A. (2008). The Complete Art of Medicine (Kamil al-Sinaat al-Tibbiyya). Qom: Jallaleddin.

5. Avicenna (2005). The Canon of Medicine (Al-Qanon fi al-Tibb). Beirut: Dar Ihyaa al-Turaath al-Arabi.

6. Bahrami, M., Shokri, S., Farahani, R. M. \& Dadmehr, M. (2020). A brief historical overview of the anatomy of fascia in medieval Persian medicine. Journal of Medical Ethics and History of Medicine, 13. https://doi.org/10.18502/jmehm.v13i7.4073

7. Binnie, A., Tsang, J. L. Y., Hu, P., Carrasqueiro, G., Castelo-Branco, P. \& Dos Santos, C. C. (2020). Epigenetics of Sepsis. Critical Care Medicine, 48(5), 745-756. https://doi. org/10.1097/CCM.0000000000004247

8. Daly, P. (2018). A concise guide to clinical reasoning. Journal of evaluation in clinical practice, 24(5), 966-972. https://doi.org/10.1111/jep.12940

9. Diamantis, A., Sidiropoulou, K. \& Magiorkinis, E. (2010) Epilepsy during the Middle Ages, the Renaissance and the Enlightenment. Journal of Neurology, 257, 691-698. https://doi.org/10.1007/s00415-009-5433-7

10. Firouzi, M., Dadmehr, M., Soltani Arabshahi, S. K. \& Bahrami, M. (2019). The earliest recorded model of clinical reasoning in Persian medicine: A historical perspective from the viewpoint of Haly Abbas. Medical Teacher, 42 (4), 481. https://doi.org/10.1080/0142159X.2019.1643458 
11. Ghaffari, F., Naseri, M., Jafari Hajati, R. \& Zargaran, A. (2017). Rhazes, a pioneer in contribution to trials in medical practice. AMHA - Acta medico-historica Adriatica, 15(2), 261-270. https://doi.org/10.31952/amha.15.2.4

12. Gurusamy, N. \& Rajasingh, J. (2019). Modern human lifestyle prejudices epigenetic changes to cuddle diseases. Annals of Translational Medicine, 7(5), 82. https://doi. org/10.21037/atm.2018.12.70

13. Heydari, M., Hashempur, M. H. \& Zargaran, A. (2013). Medicinal aspects of opium as described in Avicenna's Canon of Medicine. AMHA - Acta medico-historica Adriatica, 11(1), 101-112.

14. Iranzadasl, M., Karimi, Y., Moadeli, F. \& Pasalar, M. (2021). Persian medicine recommendations for the prevention of pandemics related to the respiratory system: a narrative literature review. Integrative Medicine Research, 100483. https://doi.org/10.1016/j. imr.2020.100483

15. Langholf, V. (2011). Medical theories in Hippocrates: early texts and the" Epidemics" (Vol. 34). Walter de Gruyter.

16. Lawson-Frost, S. (2019). An epistemological problem for integration in EBM. Journal of Evaluation in Clinical Practice, 25 (6), 938-942. https://doi.org/10.1111/jep.13109

17. Maya, L., Esteban, A., van der Graaf, A., Lanting, P., van der Geest, M., Fu, J. \& Deelen, P. (2020). Lack of Association Between Genetic Variants at ACE2 and TMPRSS2 Genes Involved in SARS-CoV-2 Infection and Human Quantitative Phenotypes. Frontiers in Genetics, 11, 613. https://doi.org/10.3389/fgene.2020.00613

18. Nikhat, S. \& Fazil, M. (2020). Overview of Covid-19; its prevention and management in the light of Unani medicine. Science of the total Environment, 728, 138859. https:// doi.org/10.1016/j.scitotenv.2020.138859

19. Nezhad, G. S. M. \& Dalfardi, B. (2014). Rhazes (865-925 AD), the icon of Persian cardiology. International journal of cardiology, 177(3), 744-747. https://doi.org/10.1016/j. ijcard.2014.11.045

20. Pappas, G., Kiriaze, I. J. \& Falagas, M. E. (2008). Insights into infectious disease in the era of Hippocrates. International Journal of Infectious Diseases, 12 (4), 347-350. https:// doi.org/10.1016/j.ijid.2007.11.003

21. Pelaccia, T., Tardif, J., Triby, E. \& Charlin B. (2011). An analysis of clinical reasoning through a recent and comprehensive approach: the dual-process theory. Medical Education Online, 16(1), 5890. https://doi.org/10.3402/meo.v16i0.5890

22. Rahimi, S.Y., McDonnell, D.E., Ahmadian, A. \& Vender, J.R. (2007) Medieval neurosurgery: contributions from the Middle East, Spain, and Persia. Neurosurgical Focus, 23, 14. https://doi.org/10.3171/FOC-07/07/E14

23. Rhazes. (1886). Al-Mansouri fi Tibb (S. HB Ed.). Kuwait: Ministry of Education, Arab culture and science.

24. Sajadi, M. M., Mansouri, D., \& Sajadi, M. R. (2009). Ibn Sina and the clinical trial. Annals of Internal Medicine, 150(9), 640-643. https://doi.org/10.7326/0003-4819-1509-200905050-00011

25. Schäfer, A. \& Baric, R. S. (2017). Epigenetic landscape during coronavirus infection. Pathogens, 6(1), 8. https://doi.org/10.3390/pathogens6010008 
26. Shoja, M. M., Rashidi, M. R., Tubbs, R. S., Etemadi, J., Abbasnejad, F. \& Agutter, P. S. (2011). Legacy of Avicenna and evidence-based medicine. International journal of cardiology, 150 (3), 243-246. https://doi.org/10.1016/j.ijcard.2010.10.019

27. Yazdani, S. \& Hoseini Abardeh, M. (2019). Five decades of research and theorization on clinical reasoning: a critical review. Advances in Medical Education and Practice, 10, 703-716. https://doi.org/10.2147/AMEP.S213492

28. Zargaran, A., Mehdizadeh, A., Zarshenas, M. M. \& Mohagheghzadeh, A. (2012). Avicenna (980-1037 AD). Journal of Neurology, 259(2), 389-390. https://doi.org/10.1007/ s00415-011-6219-2

29. Zargaran, A., Zarshenas, M. M.., Ahmadi, S. A. \& Vessal, K. (2013). Haly Abbas (949-982 AD). Journal of Neurology, 260(8), 2196-2197. https://doi.org/10.1007/ s00415-012-6823-9

30. Zarshenas, M. M., Mehdizadeh, A., Zargaran, A. \& Mohagheghzadeh, A. (2012). Rhazes (865-925 AD). Journal of Neurology, 259(5), 1001. https://doi.org/10.1007/ s00415-011-6398-x

\section{SAŽETAK}

Pregledom drevnih rukopisa perzijske medicine (PM) otkriveno je da su u prošlosti postojali neki osnouni principi za donošenje odluka o epidemijskim zaraznim bolestima. Ta PM pravila za kliničko zaključivanje primijenjena su kroz personalizirani pristup zajedno sa savjetima o javnom zdravlju u takvim situacijama. Trenutačno je pandemija koronavirusa najveći problem u svijetu. Glavni temelj liječenja koronavirusa preventivne su mjere i simptomatska obrada. U međuvremenu, tradicionalnim medicinskim sustavima za pružanje preventivne, potporne i rehabilitacijske skrbi pacijentima posvećena je veća pozornost nego prije. Prema tome, specifičan individualni pristup koji su znanstvenici PM-a razmatrali kod kliničkog tijeka epidemijskih zaraznih bolesti mogao bi pomoći u rasvjetljavanju širenja znanja o epidemijskim bolestima u drevnoj Perziji.

Ključne riječi: kliničko zaključivanje, povijest medicine, perzijska medicina, Avicena, zarazne bolesti, epidemija 
